Session 2550

\title{
Technology Teacher Education Programs in Colleges of Engineering and Technology: A Strategic Link with K-12 Education
}

\author{
Thomas Erekson, Steven Shumway \\ School of Technology \\ Ira A. Fulton College of Engineering \& Technology \\ Brigham Young University
}

Introduction

The National Science Board's (NSB) Task Force on National Workforce Policies for Science and Engineering has raised concerns about declining numbers of students pursuing engineering and scientific careers in the US in their August, 2003, report The Science and Engineering Workforce: Realizing America's Potential ${ }^{1}$. A national policy imperative was recommended by the NSB in this report:

The Federal Government and its agencies must step forward to ensure the adequacy of the US science and engineering workforce. All stakeholders must mobilize and initiate efforts that increase the number of US citizens pursuing science and engineering studies and careers. (p. 10)

Science and technology have been and will continue to be engines of US economic growth and national security. Excellence in discovery and innovation in science and engineering ( $S \& E)$ derive from an ample and well-educated workforce-skilled practitioners with two- and four-year degrees and beyond, researchers and educators with advanced degrees, and precollege teachers of mathematics and science. Current trends of supply and demand for S\&E skills in the workforce indicate problems that may seriously threaten our long-term prosperity, national security, and quality of life (p. 6). ${ }^{1}$

The Task Force also concluded that the number of native born science and engineering graduates entering the workforce will likely decline in the next decade, unless strategic interventions are implemented to improve programs that educate science and engineering students (p.6). ${ }^{1}$ This conclusion is also supported in a policy report from ACT entitled Maintaining a Strong Engineering Workforce ${ }^{2}$. An analysis of ACT data found that the percentage of high school seniors who took the ACT test and reported plans to major in

Proceedings of the 2004 American Society for Engineering Education Annual Conference \& Exposition Copyright (C) 2004, American Society for Engineering Education 
engineering in college has declined from $8.6 \%$ in 1992 to $5.6 \%$ in 2002 (Noeth, Cruce, \& Harmston, 2003, p. vi). The declining number of high school students who plan to major in engineering exacerbates the workforce situation noted by the National Science Board.

Comprehensive actions will be required to reverse these workforce trends. K-12 students need access to high quality programs in science, technology, engineering, and math (STEM) to provide the requisite educational foundation and to expose them to the possibilities of scientific and engineering careers. Likewise, university students also need high quality STEM education, especially those who are pursuing an engineering or engineering technology program.

In addition to the concerns regarding the future science and engineering workforce, there is apprehension concerning the levels of scientific and technological literacy of the general population. This issue was confirmed by the Committee on Technological Literacy (CTL), a group of experts convened by the National Academy of Engineering (NAE) and the National Research Council (NRC) Center for Education, in their report Technically Speaking. The CTL concluded:

The argument for technological literacy is rooted in a single, fundamental belief. In a world permeated by technology, an individual can function more effectively if he or she is familiar with and has a basic understanding of technology. A higher level of technological literacy in the United States would have a number of benefits, for individuals and for the society as a whole. $\left(\right.$ p. 25) ${ }^{3}$

Strengthening the Engineering and Technology Pipeline

The K-12 schools are charged with preparing students for life and for further education at the university level. Thus, they become the educational pipeline for students to enter engineering and technology programs. The pipeline, and the quality of the educational preparation in it, is critical to successful engineering and technology programs. Over the last two decades concerns have been expressed regarding the quality, or lack thereof, of K-12 education (i.e., A Nation at Risk and similar reports). If university engineering and technology faculty are concerned about the quality of K-12 schooling and in increasing the pipeline of students who pursue engineering and technology programs, these faculty need to establish and strengthen linkages with K-12 school personnel.

All too often, however, university engineering and technology faculty have little association with the K-12 schools; the teachers, the administrators, and/or the students. Given the concerns of the National Science Board and National Academy of Engineering regarding the pipeline and general technological literacy, it is evident that building strong linkages with K-12 schools should become a high priority for engineering and technology faculty. The question then becomes "how can engineering and technology faculty build strong linkages with the K-12 schools (teachers, administrators, and students) in order to strengthen the pipeline?" 
It appears that the K-12 schools and the engineering and technology educational enterprise are two very different cultures with little interaction between university faculty and K12 teachers. These perceived cultural and communication barriers need to be torn down and replaced with strong linkages and open communication. At the university level, the IEEE has sponsored two summit conferences for deans of engineering and deans of education. The purpose for these summit conferences was to open strong lines of communication between teacher education and engineering with the goal of improving K-12 education and strengthening the pipeline into engineering and technology programs. While these efforts have merit, much more needs to be done.

It is interesting to note that a few colleges of engineering operate teacher education programs, and as a result, they are uniquely situated to build strong linkages with K-12 teachers and schools. Yes, a few colleges of engineering administratively house teacher education programs and are directly involved in preparing K-12 teachers. These teacher education programs are designed to prepare middle school and high school Technology Education teachers. In all cases, the major is taught in engineering and the teacher certification, or licensure, is handled through a partnership with the education college.

The universities that are actively preparing Technology Education teachers in the engineering college, or a college that includes engineering programs, include:

- Brigham Young University

- California State University-Los Angeles

- The College of New Jersey

- University of Louisiana de Lafayette

- University of Southern Maine

- St. Cloud State University

- Utah State University

- Virginia State University

There are additional universities that prepare Technology Education teachers in the same department or college that houses the TAC-ABET accredited engineering technology programs, but not in a college that houses engineering programs. The universities include:

- Ball State University

- Central Connecticut State University

- Central Washington University

- Pittsburg State University

- Purdue University

In most of the above universities the engineering and technology faculty interact with the technology teacher education faculty on an almost daily basis. Additionally, in many instances the engineering and technology students interact with the technology teacher education students through classes, student advisory committee, and student chapters of professional associations.

Proceedings of the 2004 American Society for Engineering Education Annual Conference \& Exposition Copyright $(\mathrm{C}$ 2004, American Society for Engineering Education 
These linkages benefit both technology teacher education and engineering and technology faculty and students.

Preparation for Engineering and Technology

When engineering and technology faculty look to K-12 education they generally focus on math and science classes. High school math and science classes are generally emphasized in the preparation of students for technological careers. While math and science are essential for careers in engineering and technology, they do not give K-12 students an understanding of the goals and culture of engineering and technology.

Recently, Technology Education has emerged as a vehicle to deliver effective technological literacy education, and it shows promise for being able to deliver high quality engineering content and analytical design methods at the high school level. In fact, several state education agencies have taken steps to include engineering content as part of technology education at the secondary level (e.g., Massachusetts, Utah, Wisconsin). Curriculum projects like Project Lead the Way (PLTW) are examples of high school level engineering programs.

The release of the National Standards for Technological Literacy ${ }^{4}$ by the International Technology Education Association in the spring of 2000 places technology education in a strategic position with regards to teaching engineering content and analytical methods at the middle and high school levels. These Standards were developed under a grant from the National Science Foundation, with additional funding for NASA. It is important to note that the National Research Council (NRC) and the National Academy of Engineering (NAE) supported the development of these Standards and both groups participated heavily in their development ${ }^{5}$.

The Standards for Technological Literacy place a renewed emphasis on "design" as a core concept that is integral to technology education. Dugger, in describing the new Standards, stated the following:

The standards in Chapter 5 focus on a cognitive understanding of a design process with an emphasis on the attributes of design, the engineering design process, and other problem solving approaches. Chapter 6 deals with the design, making, development, operation, maintenance, management, and assessment of technological products and systems, emphasizing the abilities that each of these tasks demands. (p. 10) ${ }^{6}$

The Standards require that students learn both the theoretical base for design and its applications. The word "design" suggests action or actions, but actions without a theoretical base can become an exercise in futility. Likewise, providing only the theoretical base for engineering design without purposeful experiences offers the students a shallow understanding. Dugger noted this:

A student can be taught in a lecture about the design process, for example, but the ability to actually use the design process and to apply it for finding a solution to a technological 
problem comes only with hands-on experiences. Likewise, it is difficult to perform the design process effectively without having some theoretical knowledge of how it is usually done. $\left(\right.$ pp. 10-11) ${ }^{6}$

While technology studies have the potential to provide context for math and science education and engineering experiences at the middle and high school levels, it has seldom been considered part of college preparation. Erekson and Shumway made the assertion that technology education should be included as a component of a high school college preparation program ${ }^{7}$. They noted that the academically rigorous International Baccalaureate (IB) program included Design Technology as a course in the area of Experimental Sciences. The IB Design Technology course is perceived as good preparation for students who are considering studying "science, applied science, technology and engineering" in college ${ }^{8}$. The Design Technology course "provides such a student with the opportunity to deal with realistic problems and to synthesize appropriate solutions using the processes practiced during the course," especially given the teaching tool of the project method (p.6) ${ }^{8}$. At BYU, a student who completes an IB Design Technology higher-level course and exam will receive three semester hours of technology college credit.

\section{Technology Teacher Education}

There are approximately 100 colleges and universities in the US that are actively preparing technology education teachers. Most of these teacher education programs are housed in colleges of education. However, some are housed in colleges of business, colleges of professional studies, colleges of applied science and technology, and so forth. As noted above a few technology teacher education programs are housed in colleges of engineering. Two of the programs housed in engineering colleges are highlighted in the following section of the paper.

Brigham Young University, Provo, Utah

College: Ira A. Fulton College of Engineering and Technology

Departments: Chemical Engineering; Civil and Environmental Engineering; Electrical and Computer Engineering; Mechanical Engineering; School of Technology

BYU's Technology Teacher Education program is housed in the School of Technology along with the following technology degree programs: Construction Management, Facilities Management, Industrial Design, Information Technology, and Manufacturing Engineering Technology.

Faculty: The program has two FTE faculty dedicated to TTE. These faculty teach a combination of professional education courses, including supervising student teaching, and selected technical courses.

Students: The TTE program has approximately 75 students; $35 \%$ are females. 
Program: The technology teacher education program was redesigned two years ago to align with the Standards for Technological Literacy. TTE students take about 45 semester hours of technical courses. They can specialize in one of three areas; engineering, design, or visual communication. Most of the technical courses are taught by engineering, design, or technology faculty. Thus, the TTE students take several courses with engineering and technology students. They also take several professional education courses taught in the School of Education. A unique aspect of the program for those preparing to teach engineering at the high school level is the opportunity to take the two semester engineering design capstone course. This two course sequence is required for all mechanical engineering, industrial design, and manufacturing engineering technology students. In the capstone design course, interdisciplinary teams of students, under the direction of a capstone coach, conduct an actual engineering design project for a partner company.

Graduate Program: The School of Technology offers the master of science degree with an emphasis in technology education. The MS degree requires 30 hours with 6 hours required for thesis research.

Utah State University, Logan, Utah

College: College of Engineering

Departments: Biological and Irrigation Engineering; Civil and Environmental Engineering; Electrical and Computer Engineering; Mechanical and Aerospace Engineering; Engineering and Technology Education

USU's Technology Teacher Education program is housed in the Department of Engineering and Technology Education (formerly named the Department of Industrial Technology and Education; the name was officially changed in January 2004). Prior to 2004 the department also offered technology degrees in Welding Engineering Technology, Electronics and Computer Technology, Drafting, and Aviation. The welding, electronics, and drafting programs are being closed so the department can focus on engineering and technology education, including teaching first year classes for engineering majors.

Faculty: The department has four FTE faculty dedicated to TTE. These faculty teach a combination of professional education courses, including supervising student teaching, and a few technical courses.

Students: The TTE program has approximately 40 students.

Program: The technology teacher education program was redesigned several years ago to align with the adoption of technology education and it has met the NCATE teacher education accreditation requirements. TTE students take about 40 semester hours of technical courses. Most of the technical courses are taught by TTE or technology faculty. The TTE students take few courses with engineering and technology students, but interact through student clubs and professional associations. They also take several professional education courses taught in the College of Education and Human Development.

Proceedings of the 2004 American Society for Engineering Education Annual Conference \& Exposition Copyright $@$ 2004, American Society for Engineering Education 
Graduate Program: The Department of Engineering and Technology Education offers the master of science degree, the doctor of philosophy degree, and the doctor of education degree with an major in engineering and technology education. The MS degree requires 30 hours with 6 hours required for thesis research or a non-thesis option that requires 33 hours of courses. The doctoral degrees are offered in conjunction with the College of Education and Human Services.

\section{Conclusion}

To successfully increase the number and quality of the students who enter university engineering and technology programs, it is imperative that strong linkages be made between the K-12 schools and engineering and technology programs. The emergence of Technology Education as a vehicle for delivering engineering content and analytical design methods at the high school level shows great promise. In several instances the linkages between Technology Education and engineering and technology already exists, especially in the universities where technology teacher education is housed in the college of engineering and technology. It would be beneficial for engineering and technology faculty at universities where technology teacher education is not housed in their college to build bridges to their respective technology teacher education faculty. For faculty at universities that do not have technology teacher education programs, linkages can be build with local technology teachers, state offices of education technology education supervisors, and technology education professional associations.

Bibliography

1. National Science Board (August 14, 2003). The Science and Engineering Workforce: Realizing America's Potential. http://www.nsf.gov/nsb/.

2. Noeth, R.J., Cruse, T., \& Harmston, M.T. (2003). Maintaining a strong engineering workforce: A policy report. Iowa City, IA: ACT.

3. Pearson, G., \& Young, A. T. (Eds). (2002). Technically speaking: Why all Americans need to know more about technology. Washington, DC: National Academy Press.

4. International Technology Education Association. (2000). Standards for technological literacy: Content for the study of technology. Reston, VA.

5. Wulf, W. A. (2000). The standards for technological literacy: A national academies perspective. The Technology Teacher, 59 (6), 10-12.

6. Dugger, W. E., Jr. (2000). Standards for technological literacy: Content for the study of technology. The Technology Teacher, 59, 5, p. 10.

7. Erekson, T. L., \& Shumway, S. A. (March, 2002). Technology education as college prep. The Technology Teacher. 61, 6, 10-15.

8. International Baccalaureate Organization. (2001b). The diploma programme. [Online]. Available: http://www.ibo.org/ibo2/en/programmes/prg_dip.cfm 
THOMAS EREKSON is the Director of the School of Technology, Ira A. Fulton College of Engineering and Technology, at Brigham Young University in Provo, Utah. His teaching assignments include technology teacher education courses and technology-based general education courses. He can be reached at erekson@byu.edu.

STEVEN SHUMWAY is an Assistant Professor and Program Chair for the Technology Teacher Education Program in the School of Technology, Ira A. Fulton College of Engineering and Technology, at Brigham Young University in Provo, Utah. He can be reached at steve_shumway@byu.edu. 